\title{
Effects of Cashless Economy Policy on National Development: Evidence from Nigeria
}

\author{
Marshal IWEDI $^{1}$, Dumini S. IGBANIBO ${ }^{1} \&$ Chidinma UZO-AHUNANYA ${ }^{2}$ \\ ${ }^{1}$ Department of Banking and Finance Rivers State University, Port Harcourt, Nigeria \\ ${ }^{2}$ Bursary Department Captain Elechi Amadi Polytechnic Port Harcourt Rivers State, Nigeria \\ Correspondence: Dumini S. IGBANIBO, Department of Banking and Finance Rivers State University, Port \\ Harcourt, Country. Tel: 234-8033-089-449. E-mail: igbanibos@yahoo.com
}

Received: July 12, 2018; Accepted: August 6, 2018; Published: August 29, 2018

The research is financed by (Sponsoring information).

\begin{abstract}
Prior to this time, Nigeria economy was largely described as cash and paper based economy with significant proportion of the narrow money stock in form of currency outside the banking system. In a bid to drive national development, modernization of payment system and to limit the practice of the use of cash in business transaction in line with the global economy, the Central Bank of Nigeria introduced the cashless policy in January 2012 as a pilot scheme in Lagos. Since the declaration of cashless policy, there has been controversy in the academia with respect to the effects on national development some scholars believes it benefits outweigh it challenges and vice versa. Based on this therefore, this study seeks to assess the effects of cashless economy policy on national development in Nigeria. The study reveals cashless policy has promoted effective and improved monetary policy, efficient and fast payment system, job creations and increased technological infrastructures. The study suggests that government should promote efforts that will encourage cashless policy in Nigeria.
\end{abstract}

Keywords: Cashless Economy, Cashless Policy, National Development, Nigeria

\section{Introduction}

The Nigerian economy prior to this period was largely described as a cash-based and paper based economy with significant proportion of the narrow money stock in the form of currency outside the banking system (Kama \& Adigun, 2013). Following the trend in global economy where the practice of limited use of physical cash in transacting businesses is prevalent due to several adduced reasons which include the costs of printing currency and that of the life span of such currencies that always need reprinting at other times. To reduce that element of cost and in a bid to be relevant in the global market an electronic cash system of transactions was enacted in Nigeria by the Apex bank (CBN) to drive national development and modernization of payment system in line with Nigeria Vision 2020 goal of been amongst the top 20 economies by the year 2020. Furthermore, the policy helps to reduce the cost of banking services and to improve the effectiveness of monetary policy in managing inflation and achieving economic growth. Nigeria as an economy is traditionally characterized by various forms of economic crimes such as money laundering, illegal financial activity, and out-of-control inflation and leakages regarding the total stock of money issued. In order to be an economic leader of the 21 st century, Nigeria must operate an economy that is less reliant on cash, and more fluid with its payment methods and systems. The Nigeria cashless project intends to drive improvement and modernization of payment processes, minimizing the charges for banking and credit services and driving financial inclusion by offering a more effective transaction system and better reach where the disequilibrium arising from surplus spending units and the deficit- spending units can be bridged by aggregating the scattered masses of society and then disaggregating among economic units.

A cashless economy is an environment in which money is spent without being physically carried from one place to another (Adu, 2016). For Muyiwa, Tunmibi \& Afaha (2013) a cashless society therefore is a society in which no one uses cash as all purchases are made by credit cards, charge cards, cheques, or direct transfers from one account to another through mobile banking and internet services or platforms. He further asserts that the cashless society envisioned here refers to the widespread application of computer technology in the financial system. Also, Rufus and Elechi, (2016) describe a cashless economy as an economy where transaction can be done without 
necessarily carrying physical cash as a means of exchange of transaction but rather with the use of credit or debit card or other electronic media of payment for goods and services. Assessing the Nigeria's cashless project it could be concluded that the country is progressively moving toward a cashless economy where significant portion of the citizens perform payment without the use of physical cash, rather payments are made via mobile banking, internet banking, credit and debit cards, wire transfer, and cheques (CBN 2017).

However, since the declaration of cashless policy in Nigeria, there has been controversy in the academia with respect to the effects on national development some scholars believe it benefits outweigh it challenges while others are of the view that its challenges outweigh the benefits and cannot be sustainable in our kind of financial and economic environment. Based on this therefore, this study seeks to assess the effects of cashless economy policy on national development in Nigeria taking into considerations its benefits, challenges and prospect.

\subsection{Evolution of Cashless Economy and Phases of Implementation in Nigeria}

The cashless policy was introduced in January 2012 by the Central Bank of Nigeria as a pilot scheme in Lagos. The policy stipulates a free cash withdrawal and lodgments by individual and corporate customers on a daily cumulative limit of $\# 150,000$ and $\# 1,000,000$ while a cash handling charges is stipulated on any daily cash withdrawals that exceeds $\# 500,000$ for individual and $\# 3,000,000$ for corporate entities (CBN 2012). Despite the laudable objectives, the implementation of the policy was withheld shortly after the conclusion of the pilot scheme in Lagos after concerns were raised as to the workability of the policy at nationwide scale. The major worry was the capacity and ability of the Nigeria banks and industry stakeholders to achieve a nationwide rollout by providing stable, efficient, and easily accessible infrastructure across the nation (Akeem, 2017). The fears were that if the use of cash was being penalized and cashless alternatives were not available, accessible, reliable, or trusted, then the objectives of the policy would not be achieved. Indeed, there was a strong fear that Nigerians would revert to storing their cash deposits outside of the banking system. But with the policy recording a huge success in Lagos, informed the decision of the CBN to extend the cashless policy to six other states of Kano, Rivers, Anambra, Abia, Ogun and Abuja in 2013 while in July 2014 saw the implementation of the policy nationwide.

After the tenure of the former CBN Governor Lamido Sanusi Lamido, not much has been heard of this policy. In 2017, there was a renewed drive to implement the cashless policy reintroducing ceilings, penalties, and charges across various locations of the country in phases. The cashless policy aims to reduce and probably transfer the high cost associated with volume of cash handling along the value chain from the $\mathrm{CBN}$ and bank to corporations and traders.

Table 1.

\begin{tabular}{cccc}
\hline \multirow{4}{*}{ Individual } & Amount & Deposit & Withdrawal \\
\cline { 2 - 4 } & Less than $\# 500,000$ & Free of Charge & Free of Charge \\
& $\# 500,000-\# 1,000,000$ & $1.5 \%$ & $2 \%$ \\
& $\# 1,000,000-\# 5,000,000$ & $2 \%$ & $3 \%$ \\
& Above $\# 5,000,000$ & $3 \%$ & $7.5 \%$ \\
& Less than $\# 3,000,000$ & Free of Charge & Free of Charge \\
Corporate & $\# 3,000,000-\# 10,000,000$ & $2 \%$ & $5 \%$ \\
& $\# 10,000,000-\# 40,000,000$ & $3 \%$ & $7.5 \%$ \\
& Above $\# 40,000,000$ & $5 \%$ & $10 \%$ \\
\hline
\end{tabular}

Source: CBN (2017)

The new charges took effect from the 1st of April 2017 in the following states: Lagos, Ogun, Kano, Abia, Anambra, Rivers and the FCT. Also, the policy was implemented with the charges taking effect on 1st May 2017 in the following states; Bauchi, Bayelsa, Delta, Enugu, Gombe, Imo, Kaduna, Ondo, Osun and Plateau. While on 1st August 2017 the charges was implemented in the Edo, Katsina, Jigawa, Niger, Oyo, Adamawa, Akwa-Ibom, Ebonyi, Taraba and Nasarawa. Finally on $1^{\text {st }}$ October 2017 the charges was implemented in the following states Bornu, Benue, Ekiti, Cross-River, Kebbi, Kogi, Kwara, Yobe, Sokoto and Zamfara.

However, in $20^{\text {th }}$ April, 2017, the CBN issued a circular mandating deposit money banks operating in the country to suspend charges on over the counter or ATM withdrawal of above $\# 500,000$ or deposit of same amount. According to CBN all the charges introduced in February and meant to take effect from April 12017 have been suspended while existing policy as implemented in Lagos and six other states of Kano, Rivers, Anambra, Abia, 
Ogun and Abuja in 2013 remains. The further stress that banks should revert to the old charges as follows: individual withdrawal or deposit charges is 3 percent while 5 percent is for corporate account for withdrawal or deposit in above \#3,000,000 cash.

\section{Channels Promoting Cashless Policy in Nigeria}

The cashless policy as designed by the $\mathrm{CBN}$ is one that provide mobile payment services, reduce the traditional bottleneck of financial inclusion and offer low cost, secure convenient financial services to urban, semi-urban and rural services across the Nigerian Economy. There are several channels of electronic payments in Nigeria that promotes cashless economy. They include:

\section{ATM}

According to Okafor (2008) the ATM as an electronic device which allows a financial institution's customer to use a secured method of communication to access their accounts, make cash withdrawals or cash advances using credit cards and checking their account balances without need for human teller or cashier. Also, ATM is a machine designed for making variety of online payments such as utility bills, T.V subscriptions, GSM recharges etc. However, available statistics on various e-payment channels in Nigeria as reported by CBN indicate that number of ATMs stood at 17,712 with an active card user of 29.24million people, while the volume and value of transactions amounted to 336.77 million and N3.05 Trillion, at end-June 2017, respectively (CBN, 2017).

\section{POS Terminal}

Point of Sale terminals are deployed to merchant locations where users slot their electronic cards through POS in order to make payments for purchases or services instead of using raw cash. As the POS terminals are online realtime, the customer's bank account is debited immediately for value of purchases made or services enjoyed. However, in Nigeria, the Point of Sale (PoS) terminal was introduced by the CBN to drive home its cashless policy aimed at enhancing Nigeria payment system. Since its introduction in 2012, the initiative has recorded tremendous success across the country. Available data shows that CBN have deployed over 126,608 PoS with a volume of 59.42million and 610billion as total value as at June 2017 (CBN, 2017).

\section{NIBSS Fund Transfers}

The Nigerian Interbank Settlement Scheme is an online platform where banks exchange value thereby enabling the performance of interbank transfer such as NEFT and NIBSS instant transferring funds between banks for single or multiple beneficiaries for individual amounts not exceeding N10million. NEFT transfers (National Electronic Funds Transfer), once affected works with the next available clearing session of CBN and is received in the beneficiary's account the same day or next working day, but NIBSS instant payments are immediate.

However, in 2017, NEFT suffered contraction, as value of its transactions, which contracted by 4.0 per cent in 2016, contracted by 5.0 percent in 2017. It volume and value of transactions dropped by 7 percent and 4 percent respectively to 23.6 billion from N11.9 trillion in 2017 from 25.3 billion and N12.4 trillion in 2016.

\section{Mobile Money}

This is a product that enables users to conduct fund transfer, make payment or receive balance enquiries on their mobile phones. NIBSS data showed that as at June 2017, total number of customers using mobile money stood at 2.3 million with a transaction volume of 24.17 million at a value of N555.83billion. Furthermore, it is also on record that the total number of agent enrolled under this platform stood at 5,517 in 2017 while 21 operators were fully licensed.

\section{Web- transfers (Internet)}

It refers to electronic transfers which can be affected via the internet on (Personal Computers) PCs, laptops and other devices. Bank customers who have subscribed to internet banking can do basic banking transactions via the web. NIBSS data showed that as at January through June 2017, Web transfer records a total transaction volume of 11.49 million at a value of N83.67billion.

\section{Cashless Policy and National Development in Nigeria}

The effects of cashless economy policy on national development in Nigeria include:

\section{i Effectiveness and Improvement of Monetary Policy}

The policy has impacted the economy positively in the area of management of inflation and economic growth development. Cashless policy targets at reducing the volume of physical cash in circulation while inflation is the persistent rise in the general price level of goods and service in the economy due largely to excess liquidity. The policy helps in reducing excess liquidity in the system by placing daily cash withdrawal limits for individual and 
corporate account holders. In so doing, the inflationary pressure in the economy is reduced.

\section{ii Faster Payment and Clearing System}

The cashless economy policy has help to reduce or eliminate bureaucratic nature associated with clearance and payment for goods. According to Adu (2016) the Nigeria custom service has a payment system that is cashless in nature where government account is credited electronically with the right amount of money due her. This of course in turn has easily facilitated the clearance of goods by importer. Also, through the E- banking platform, cashless policy has aided the prompt settlement of business transaction locally and internationally by reducing long queens both at the banking hall and point of sale terminals nationwide.

\section{iii Increase in Public Sector Revenue Generation}

Cashless economy policy significantly contributed to the huge success recorded by the government in the rising profile of revenue generation in Nigeria. Together with the help of Cashless policy and Treasury Single Account (TSA) system all tax and non-tax revenues are collected and payments made correctly in a timely manner to a unified structure of government bank accounts while government cash balances are optimally managed to reduce borrowing costs (or to maximize returns on surplus cash). it has also help in plugging loopholes and reducing the incidence of fraudulent practices of diverting government funds to individual pockets.

\section{iv Promotion and Increase Job Generation}

Cashless policy has help in creating jobs for millions of Nigerians who now operate mobile money shop across the nooks and cranny of the country. Available statistics from NIBSS shows that as at June 2017 5,517 agents are enrolled to operate mobile money shop in Nigeria with 21 licensed mobile money operators (MMOs). The report further reveals that the total volume of transaction of the class of E-payment stood at 24.17million with a transaction value of N555.83billion. Muyiwa, Tunmibi \& Afaha, (2013) in their study document that cashless policy has increase employment generation by $11.1 \%$, cash related robbery and cash corruption case have declined by $22.2 \%$ and $33.3 \%$ respectively while it has attracted more foreign investment by $33.3 \%$.

\section{v. Increased and Improved Technological Infrastructure}

The introduction of cashless policy in Nigeria has brought about increased and improved technological infrastructure in the country. The level of infrastructure in place now cannot be compared to what we have at the introduction phase of this policy. Information and communication technology coverage has tremendously increased; people can now do banking and other businesses at the comforts of their home and offices using mobile phones and other information technology gadgets. The number of ATMs and PoS has doubled; available statistics from CBN (2017) reveals that as at June 2017, the total number of point of sale terminal in this country stood at 125,608 while ATMs stood at 17,712.

\section{Challenges of Cashless Policy in Nigeria}

Inspite of the benefits there are challenges hampering the efficacy of cashless policy in Nigeria. They are

\section{i Lack of Confidence:}

There is this lack of confidence by the citizens on the cashless system due largely to the many disruptions associated with it.

\section{ii Erratic Power Supply and Communication link}

Power failure negatively affects e-banking infrastructures like ATM, network failure of communication link due to much congestion, change in weather also affect the policy.

\section{iii Telecommunication Network Issues}

Due to the incessant interruptions by power supply and the telecommunication failures related with the policy, congestions and many other encumbrances, etc.

\section{iv Non- Existence of Computer Back-up}

There is bound to be total loss of data on customers' accounts if there is no back up and the entire file is damaged. This may lead to misappropriation of customers' account, hence bank should maintain back up of all its information outside the bank's premises.

\section{$v \quad$ Low level of Internet Penetration}

Most banks find it difficult to fund procurement of modern equipments needed for e-banking. Nevertheless, there has been tremendous improvement in automation of bank operation in the country in the last 5years but there are still rooms for further expansion so as to catch up with hi-tech, which is in vogue in developed countries; 


\section{vi Replacement of workforce by machine}

Electronic banking has now somehow reduced the number of employees needed to handle most transactions in the bank as most work done by workers are now being handled by machines thereby translating to increase in the rate of unemployment in the country.

\section{vii High bank charges for the use of e- banking Machines}

Commission charged by bank on ATM transactions, as an example, is too high, thereby discouraging customer from using it; Central Bank of Nigeria is working out a modality to stop forthwith charges for usage of ATM.

\section{Conclusion}

The study concludes that the CBN cashless policy has change a lot of things in the financial system in particular and the economy in general. The impact of this policy cannot be overemphasized; it has positively promoted effective propagation of monetary policy, fast and modernize payment system, job creation and robust technological infrastructure among others. Based on this, we suggest that efforts aimed at promoting cashless economy should be encouraged while government should provide effective and workable framework that will promote and drive the full implementation of cashless policy in Nigeria.

\section{Reference}

Adu, C. A. (2016). Cashless Policy and its effects on the Nigeria Economy. European Journal of Business, Economics and Accounting, 4(2), 81-88.

Akeem, O. L. (2017). The second coming of cashless and the rise of the "Fintech". Retrieved from https:/techpoint.ng/2017/03/20/cashless-nigeria-rising-fintechs/

Central Bank of Nigeria. (2012). Guideline on point of sale and acceptance services in Nigeria.

Central Bank of Nigeria. (2017). Electronic Payments fact sheet for June 2017.

Kama, U., \& Adigun, M. (2013). Financial Inclusion In Nigeria: Issues and Challenges. Central Bank of Nigeria. Occasional Paper No.45.

Muyiwa, O., Tunmibi, S., \& Afaha, J. (2013). Impact of Cashless Economy in Nigeria. Greener Journal of Internet, Information and Communication System, 1(2), 40-43. https://doi.org/10.15580/GJIICS.2013.2.020713436

Okafor, L. (2008). Nigeria Payments System: The Role of the Banking Industry. Paper Presented at the CBN Seminar on the Dynamics of Managing the Nigeria Payment System in the 21st Century.

Rufus, A., \& Elechi, A. C. (2016). Cashless Policy in Nigeria and its Socio-Economic Impact. International Journal of Humanities and Social Sciences Research, 2(12), 35-40.

\section{Copyrights}

Copyright for this article is retained by the author(s), with first publication rights granted to the journal.

This is an open-access article distributed under the terms and conditions of the Creative Commons Attribution license (http://creativecommons.org/licenses/by/4.0/). 